\title{
Incorporating Innovation and Reforms in Philosophy of Education and Practice of Teacher Educational Management in Nigeria
}

\author{
Stanley U. Nnorom, Benignus C. Nwankwo, Ezenwagu Stephen
}

\begin{abstract}
The paper examines incorporating innovation and reforms in philosophy of education and practice of teacher educational management in Nigeria. The changes and development that take place in the society infiltrate into the school system and influence the actions and activities in the system. In recent times, educational establishments are facing the challenge to do more with fewer resources as they try to meet the complex and changing demands of the society. The effective management of educational institutions depends on the quality of the institutional administrators, their qualifications, experiences and professional exposure. We are living in a knowledge driven society in which technological development has turned the world into a global village. There is need to catch up with the changing needs of institutions as well as coping with meeting the challenge of individual reforms that looks a daunting task, all of them to be achieved within a limited time frame presents a management challenge that thus requires planning. . The nations of the world, of which Nigeria is a part, are also becoming more interconnected and interdependent. To avoid possible "future shock" nations must respond quickly, preferably and proactively to these rapid changes. Effective management is a sine-qua-non to the successful implementation and institutionalization of curriculum change in order to achieve the desired goals. The paper in details described innovation in education, Conceptual review of philosophy and philosophy of education, philosophical practice on teacher education, reforming teaching as a high level profession management and sphere of educational management in Nigeria.
\end{abstract}

Index Terms - Education, Innovation, Philosophy of Education, Educational Management.

\section{INTRODUCTION}

Education is a vital tool for inculcation and transmission of the right values, attitudes, and skills necessary for the development of individuals and the society at large (Seya, 2014). In the traditional African Society, the purpose of education was very clear and functionalism was its main guiding principle (Fafunwa, 1974). The traditional African society, including Nigeria, regarded education as a means to an end and not an end in itself. It was a necessary induction into the society and the responsibility was shouldered by the parents in their respective homes and the elders in the society. Education then emphasized social responsibility, job

Stanley U. Nnorom, Department of Educational Management and Policy Nnamdi Azikiwe University, Awka Anambra State.

Benignus C. Nwankwo, Department of Education Foundations, Nnamdi Azikiwe University, Awka Anambra State.

Ezenwagu Stephen, Department of Educational Management and Policy Nnamdi Azikiwe University, Awka Anambra State orientation, political and social participation as well as spiritual and moral values. According to Nakpodia (2011). education is described as the process of facilitating learning, knowledge, skills, values, beliefs, and habits of a group of people are transferred to other people through storytelling, discussion, teaching, training or research, which are educational processes.

According to (Ukeje, 1988 in Wanekezi, Okoli and Mezieobi, 2011), pointed out that education unlocks the door to modernization and sustainable development but that, it is the teacher that holds the key to the door. Thus, the teacher has the responsibility of translating educational policies into practice and programmes into action. It is clear from the foregoing that the role of the teacher in sustainable development cannot be quantified, especially in training personnel in various areas of the workforce. For national development and peaceful co-existence to be attained, there is need to give priority to investment in human capital through teacher education and training. The Nigerian educational system needs to be responsive to the technological social and economic needs of the society and provide the type of human resources needed in the industrial and economic sector. Herein comes the role of effective teacher education programme to translate the needed skills, knowledge and attitudes to meet their needs and the societal ones.

Education worldwide is formally divided in stages such as Pre-school, Primary school, Secondary school, and college, or University. Educational methodology is also called pedagogy. Pedagogy is a term that helps us to understand and describe how teachers cultivate, nurture, sustain and indeed transform learners. It encompasses the goals, the professional knowledge and beliefs, the selection of curriculum, the design of learning, the classroom organization, the teaching and learning strategies, the style of lesson delivery, the nature of student interaction, the forms of control and discipline, and the methods of assessment chosen by the teacher and enacted in the classroom.

A right to education is government prerogatives to citizens globally (Armstrong, 2015) he further stressed that the Article 13 of the United Nations 1996 International Covenant on Economic Social and Cultural Rights recognizes the right for education to all Similarly, Nnaji (2006) sees education as the wealth of knowledge acquired by individual after studying particular subject matter or experiencing life lessons that provide comprehension of something. This means that education requires instruction from an individual or composed literature. 
Education involves a systematic training and instruction that prepares an individual for the future (Akpan-Atata et al, 2014). It involves acquisition of knowledge, ability, skills, development of character and mental power resulting from such training and instruction. One important fact in education is the building of knowledge or creation and sharing of knowledge with the learners so that at the end of schooling the individual acquires the necessary knowledge, skill and expertise that will enable the person to develop him/her and also contribute constructively to the development of the nation

It is generally believed that education holds the key to national development and no nations' education go beyond the quality of its teachers. With this development, Nigerian education needs improvement and innovation on the quality of teachers. The task of imparting knowledge especially in a world that has been reduced to a global village through science and technology with its attendant challenges, effort must be put in place for Nigerian teachers to carry out this task. In this regard Balogun et al (2001) regrets that most institutions preparing the teachers in Nigeria are scant in the preparation for modern day materiality. In light of this, the paper is a discourse on incorporating innovation and reforms in philosophy of education and practice of teacher educational management in Nigeria. Innovation in Philosophy of education will entails changing the method education is perceived. New practice in this paper would suggest an innovation in approach, methodology and other activities involve in education.

\section{What is Innovation in Education?}

However, Education Innovation (Seya, 2014) encourages teachers and students to explore research and use all the tools to uncover something new. It involves a different way of looking at problems and solving them. The thinking process that goes into it will help students develop their creativity and their problem solving skills. Many mistakenly believe innovation has to do with the use of technology or new inventions. In "Four Dimensions of Innovation in Education," Falch et al (2015). To do something differently requires coming up with an approach, process, product or strategy. He further explains that outdated thinking of how to design a school leads to subpar performance in public education. "Learning experiences could be redesigned to be far more relevant to student interests and career paths, personalized to their aptitudes and abilities, and responsive to their culture and identities," he writes. Innovation in education encourages teachers and students to explore research and use all the tools to uncover something new. It involves a different way of looking at problems and solving them. The thinking process that goes into it will help students develop their creativity and their problem solving skills. Innovation does not mean creating something from nothing. Just like with any good science project, it relies on researching existing solutions to come up with a new hypothesis to test. "Original research is critical to our education system's overall success," writes (Vadim, 2018) in "Innovation in Education Is More than a New Approach." "I firmly believe that proving -- or disproving -- hypotheses with strong rigorous research is the best way to move education forward." Innovation improves education because it compels students to use a higher level of thinking to solve problems.

\section{CONCEPTUAL REVIEW}

\section{Philosophy}

Philosophy has had a long history in the Western traditions as having had a variety of definitions and usages within the bounds of changing times and contexts. Unfortunately, the first embarrassment which even the professional philosopher experiences is the fact that he cannot forthrightly produce any succinct or a universally agreed definition of the profession. For that reason, even the question, "what is Philosophy?" has turned to be a Philosophical question Iwuchukwu (2003). According to Lucas (1969:2) sighted in Iwuchukwu (2003) in trying to define philosophy draws our attention to the agreement put forward by Wittgenstein that:

The questions of philosophy do not arise

From ignorance of facts but from confusion about what is in one way familiar. Philosophy is a response to that sense of bafflement about what we know but do not understand.

Philosophy (from Greek philosophia, 'love of wisdom') is the study of general and fundamental questions about existence, knowledge, values, reason, mind, and language. Such questions are often posed as problems to be studied or resolved (Wikipedia). Philosophy according to Omeregbe sighted in Odionye (2014) is man's quest for the unity of knowledge; it is the rational search for answers to the questions that arise in the mind when we reflect on human experiences.

\section{Philosophy of Education}

A philosophy of education is a statement (or set of statements) that identifies and clarifies the beliefs, values and understandings of an individual or group with respect to education. ... A philosophy of this sort is critical in defining and directing the purposes, objectives and focus of a school. A clear educational philosophy seeks to identify and elucidate broader, often implicit, principles and themes that are not necessarily exemplified in a school's textbooks or syllabus, but are consistent with the beliefs and values that define and focus the vision and mission. Brave Hearts Bold Minds brochure provides the broader framework of this philosophy across our four phases of development - Early Years, Junior Years, Middle Years and Senior Years. The Melbourne Declaration on Educational Goals for Young Australians (MCYEETA 2008) states that, "schools play a vital role in promoting the intellectual, physical, social, emotional, moral, spiritual and aesthetic wellbeing of young people." However, without a clear educational philosophy to guide and direct our educational choices, directions and priorities in these broad categories, our children are nurtured in a learning environment determined by some collective 'best guesses' and strong individuals. The Purpose of Education in Nigeria Education, whether it is formal or informal, has a purpose. The purpose and goal of education in Nigeria is contained in the Section I of the National Policy on Education (NPE) (2004). According to the document, "no policy on education, however, can be formulated without first 
identifying the overall philosophy and goal of the nation" (NPE, 2004, p.1). This therefore means that the purpose of education in Nigeria is to serve as the vehicle towards achieving the national goals and philosophy of Nigeria. As outlined in the NPE 2004, the national goals and philosophy of Nigeria are as follows:

(a) To live in unity and harmony as one indivisible, indissoluble, democratic and sovereign nation found on the principles of freedom, equality and justice.

(b) To promote inter-Africa solidarity and world peace through understanding.

(c) To build a free and democratic society.

(d) To build a just and egalitarian society.

(e) To build a great and dynamic economy.

(f) To build a land full of bright opportunities for all citizens. To achieve this goal, education in Nigeria therefore must be directed towards:

(a) The inculcation of national consciousness and unity.

(b) The inculcation of the type of values and attitude for the survival of the individual and the Nigerian society.

(c) The training of the mind in the understanding of the world around.

(d) The acquisition of appropriate skills and the development of mental, physical and social abilities and competences as equipment for the individual to live in and contribute to the development of the society. In consequence, education has to be oriented toward inculcating the following values:

(a) Respect for worth and dignity of the individual.

(b) Faith in man's ability to make rational decisions.

(c) Moral and spiritual principle in inter-personal and human relations.

(d) Shared responsibility for the common good of society.

(e) Promotion of the physical, emotional and psychological development of all children.

\section{Philosophical Practice on Teacher Education}

Nelson Mandela once said, "Education is the most powerful weapon you can use to change the world." The teacher imparts education hence the role of the teacher is of paramount importance both in the present and the future of a student. The new philosophy is the philosophy adaptation and adjustment where teacher education must adapt and adjust to the new realities of the complex society and the demands of globalization (Ortese, 2009). The new philosophy is that which advocates for a pragmatic and more functional teacher education which is learner centred. This innovative philosophy believes in the development of the teachers as regards the use of modern facilities to ensure effective classroom activities. Teachers serve the society by instructing and guiding countless students through the different stages of their growth (Emenike 2010). They prepare them to take on the world which they are a part of. The teacher must play different roles in a student's life.

It is a philosophy that calls for teacher education that produces creative teachers who will in turn produce creative citizens (Nwazuoke, 2002). He must be his friend stirring him clear from murky waters, he must be his guide helping him find his true calling in life, and he must be a philosopher enlightening his young audience about the ways of the world. As the students grow the teachers play a very important role in shaping the students future (Ogbole and Balogun 2001). The seeds are sown when the mind is young. It is the teacher who must now not only help the student decipher the facts and the figures, he must be his confidant and his counsel. It is important that a teacher befriend his students because students respond better to friendship than to authority. If the student perceives his teacher as his friend he will not be hesitant in airing his doubts. Students are deeply impressed by their teachers, and are prone to emulate their characteristics.

A popular teacher becomes the ultimate role model for his pupils. Ezeani (2013) Teachers genuinely play an important role in society. They can make or break a future generation; such is the power that rests in the hands of the teachers. The students are like the clay and the teachers are like the potters that shape their destiny. Education is the key to development and the teacher is the major determinant factor in the nation's education; teacher education must take the right dimension. Teacher education must mentally emancipate its recipients who will apply workable educational approaches and methodology to mentally emancipate young Nigerians (Woodrow, 2010). In a nut shell, Philosophical Practice on Teacher Education calls for a change in the method teachers and teacher education is perceived in the global society like Nigeria to a new perception where the teacher is seen as a factor that cannot be neglected.

\section{Innovation in the Designs of Teacher Education}

It is important to identify the main possible design of teacher education, and the trade-offs in terms of cost-efficiency that exists between their different phases. Alternative pathways vs. traditional pathways: Complementary teacher certification and accreditation mechanisms can be designed to manage the risk of seeing the quality of teachers lower as a consequence of this new development. For a country, an option could be the development of alternative pathways, as long as it is carefully assessed and designed comprehensively and coherently.

Initial teacher education vs. continuing training: there is a certain complementary between both phases of the education continuum. Initial teacher education could be shortened, and the resources economized could be used to strengthen continuing training, based in schools. For Nigeria, this change is worth consideration, but would need careful assessment. Even if continuing training should not have to compensate for a bad quality initial teacher education, in the case teachers do not have a sufficient level to teach, such measures could "correct", and compensate this "deficit" in teaching skills and knowledge.

\section{REFORMING TEACHING AS A HIGH LEVEL PROFESSION MANAGEMENT IN NIGERIA}

Rethink the content of teacher education to attain teacher quality: The method in which practicing teachers learn depends on many factors - culture and tradition, existing institutions, systemic characteristics, etc. Specific designs of teacher education must be context specific, and modeled in function of specific needs (education aims, processes that are 
already in-place, developing these skills and to understand the in depth context of the schools in which they teach. Teacher education programmes in Nigeria should be designed as an incentive to bring the right people into teaching and to make it adequate to the country's specific needs, depending on the quality and the quantity of future teachers that it is considered suitable.

Increase the coherence between the education received by teachers and what actually happens in the classrooms: The role of practical field-experience in teacher education has to be revaluated: to include practicum during initial teacher education allows to familiarize aspirant teachers to classrooms, to prevent "reality-shocks" at the beginning of their teaching career, to link pedagogical theory with practical problems and to construct a sound professional identity. The modalities (sole observation, tutoring and assistance, full responsibility of a class, small support tasks) can be adapted to the particular context of each country. Research shows that soon-to-be-teachers that have had an extensive training in schools perform better as teachers. Systematically put into place teacher quality mechanism: Systematic certification for teachers and accreditation for teacher education providers have to be put into place. Educational managers can establish professional standards, independently to what is taught in the teacher education programmes. This is also a way to influence on these programmes, and make their outcome closer to what the educational system needs, in terms of skills and competences. To raise the requirements to certify teachers allows improving teacher quality. The establishment of standards to certify teachers, and/or to accreditation teacher education providers can allow to "even out" teacher education, to bring clearness and predictability into the system.

\section{SPHERE OF EDUCATIONAL MANAGEMENT IN NIGERIA}

Educational management acts across a wide range of activities that occur within a formal educational system, aimed at improving the conduct of teaching and learning. Babalola (2006) has this comprehensive view of educational management in mind when defines management as involving strategizing, planning, organizing, directing and supervising the entire process of teaching and learning that takes place in all level of formal educational system. Peretomode as sighted in Ezeugbor and Anozie (2019) brings planning to the centre of educational management when he defines the term, educational management as concerned with the planning and formulation of educational policies and programmes with view to achieving educational goals. The national policy on Education (FRN) (2013:55) agrees that proper planning is essential to efficient educational delivery, but adds that administration included organization and structure, proprietorship. This document multifariously concerns of educational management consists not only of teaching and learning processes in the classroom but also including the activities of officials of the ministry of education, state education commissions, political manifestos, policymakers and planning, supervision and inceptives. Lunnenberg and
Orstein sighted in Ezeugbor and Anozie (2019) viewed the following activities could be coalesced into educational management

1. Management of the instructional processes; Management of those activities that aid effective delivery of instruction is regarded as the supreme managerial function and the ultimate responsibilities of a school head. The major administrative area include:
a) Methods of instructional delivery
b) Use of instructional materials
c) Students Evaluation
d) Timetabling and academic calendar.

2. Personnel Management: Involves the series of steps directed at making use of school staff both tutorial and non tutorial to realize the objectives of the school. Included in personnel management duties in a school are the following:
a) Staff recruitment
b) Staff orientation
c) Staff development
d) Staff motivation
e) Staff supervision

3. Students' management: the student management is crucial aspect of school management because if there is no student, there will be no key to managerial areas like instructional and personnel management. Oku et al (2013) lay down vital activities in student/pupil management:

a) Management of admission and classification of students

b) Provision of Adequate teaching and learning facilities.

c) Guidance and counseling, health and safety programmmes

d) Logistics for transportation

e) Enforcement of discipline

4. Financial Management: finance is the live wire of any organization. (Ogunna, 1999; Oku et al (2013) viewed the following involved in the management of finance for educational institution:

a) Specifying the programmes and project to be carried out

b) Estimating expenditure required to carry them out

c) Identifying the anticipated revenue to be used in accomplishing this aims.

5. Community Relations: school: School do not operate in a vacuum, they are functional entities in definite social settings and as such must relate well with other units for smooth function of the system. Base on this, Oku et al (2013) observe some important activities that must be effectively managed for harmony to be maintained between the school and the social system in which it operates.

a) Learning and comprehending the community

b) Making the community to be informed of the objectives, aims programmes and needs of the school. 
c) Constant interaction between the school and the community updates each others knowledge on any innovation.

d) Collaborating with the important agencies in the community like traditional rulers, local government authorities, town union groups, PTA, Alumni associations social clubs and other relevant personnel.

\section{CONCLUSION}

Teacher Education has grown over time. They are treasured all over the world as drivers to traditional economic and social development. However the teachers have consistently been ignored by local, state and federal governments. This neglect has grossly affected teachers' condition of service. Unqualified and untrained are appointed as teachers these has an affected teaching profession. Turning to the classics of innovative pedagogy, it is necessary to look for practical methods to implement the normative and legal documents of Nigeria on issues of innovation in education, namely: to pay attention to the terminology, purpose and principles of state innovation policy, objects of innovation activity, subjects. It is important to emphasize that innovations are determined by newly created or improved competitive technologies, products or services, as well as organizational and technical decisions of an industrial, administrative, commercial or other nature that significantly improve the structure and quality of production or social sphere. When educational innovations recognize the improved or applied educational, didactic, educational management systems, their components, which significantly improve the results of educational activities and reforms.

\section{REFERENCES}

[1] Akpan-Atata E.A., Eyene E., Sam G. (2014). Creativity and innovation in library science and information management in academic libraries. Paper presented at 1 st global conference on creativity and innovation. Akwa-ibom state university auditorium, 12th - 16th may 2014.

[2] Armstrong M. and Taylor S. (2015), Armstrong's handbook of human resource management practice, London: Kogan.

[3] Babalola, J.B. (2006) Overview of educational management. In J.B. Babalola, A.O. Ayeni, S.O. Adedeji \& Arikewuyo M.O. (eds.) educational management: thoughts and practices. ibadan: codat publications.

[4] Emenike, C.N (2010) Quality control assessment in tertiary institution in Nigeria. Journal of education 3(2)23-26.

[5] Ezeani, E (2013) A philosophy of education for African nations ( $2^{\text {nd }}$ Ed.) London: VERITAS lumen publishers.

[6] Ezeugbor, C.O. and Anozie, P. O. (2019) Educational management. A new dimension. Printed and published by scoa heritage ltd Awka, Anambra State, Nigeria.

[7] Fafunwa, A.B (1974). History of education in Nigeria. London: Macmillan publishers.

[8] Falch, T. Mang, C. (2015) Innovations in education for better skills and higher employability, European expert network on economics of education, 2015.

[9] Federal Republic of Nigeria (2004) National policy on education. Lagos: Nerdc

[10] Federal Republic of Nigeria (2013) National policy on education ( $^{\text {th }}$ ed.) Abuja: federal ministry of education.

[11] Iwuchukwu, C.B (2003) Philosophy of education. A first course volume (1) revised edition. Printed and published by cel-bez \& co. publishers' Owerri, Imo state, Nigeria.

[12] Nakpodia E.D. (2011). Teacher factors in the implementation of universal basic education programme in junior secondary schools in the south senatorial district of delta state, Nigeria. Journal of public administration and policy research, 3(10): 286293.
[13] Nnaji V. (2006) "The problem of implementing 6-3-3-4 system of education in junior secondary schools in Nkanu west L.G.A", an unpublished b. Ed project Enugu state university of science and technology, Enugu

[14] Nwazuoke, L.O (2002) Education for creativity and self reliance, journal of educational research and development. 2(4) 55-66.

[15] Odionye, E.A (2014) Philosophical foundations of education. Owerri: pasco graphics.

[16] Ogbole, D.M and Balogun, J.O (2001) Rudiments of teacher education in nigeria. panshin: academic trust fund.

[17] Ogunna, A.E.C. (2004) Fundamental principles of public administration. owerri: great versatile publishing company ltd.

[18] Oku, O.O., Emenalo, F.C. \& Okeke, F.N. (2013) Fundamentals of educational administration and supervision. ( $2^{\text {nd }}$ ed.) eket: corporate impressions.

[19] Ortese, H. (2009) Issues in creative education. ibadan: digital crew publishers ltd.

[20] Seya P. T. (2014). Adult education and African development in the context of globalization. http://www.dvv-international.de/index.php?article-id=230\&clang=1.

[21] Vadim P. (2018) Home articles education articles why innovation absolutely matters in education published on: january 08, 2018 nwmissouri.edu | 844-890-9304

[22] Wanekezi, A. U., Okoli, J and Mezieobi, S. A., (2011). Attitude of student-teachers towards teaching practice in the University of Port Harcourt, Rivers State, Nigeria. Journal of Emerging Trends in Educational Research and Policy Studies (JETERAPS) 2, (1): 41-46.

[23] Wikipedia. (2013).definition of education philosophy. retrieved 12th may, 2014 .from: http://en.wikipedia.org/wiki/evaluation research.

[24] Woodrow, G.N (2010) Educating the Mindset. London: Cruchrt Press. 